\title{
Pemikiran Parni Hadi tentang Jurnalisme
}

\author{
Feri Purnama ${ }^{1} *$ \\ ${ }^{1}$ Kantor Berita Nasional Antara \\ * email. antaraferi@gmail.com
}

\begin{abstract}
Parni Hadi's Thought Study of Prophetic Journalism about the dissemination of information based on faith, and good and bad renewal in society. Parni Hadi as a press figure supports his prophetic journalism as a way of preaching and the legacy of the prophet's duty to be applied in journalistic practice. This study analyzes Parni Hadi about Prophetic Journalism, Islamic Journalism, and implementing Prophetic Journalism. The library research methodology (literature study) uses content analysis methods. This study found that Prophetic Journalism can be practiced by journalists or mass media religious backgrounds, as long as presenting the right journalistic products, educating and to help all people, while still using the prophet's duty on honesty, help, be reliable, educate and send a message full of wisdom .
\end{abstract}

Keywords: journalism thinking, Parni Hadi, prophetic journalism

\begin{abstract}
ABSTRAK
Penelitian Pemikiran Parni Hadi tentang Jurnalisme Profetik ini tentang penyebaran informasi yang dilandasi iman, dan mempertimbangkan dampak baik dan buruk di masyarakat. Parni Hadi sebagai tokoh pers memiliki gagasan jurnalisme profetiknya sebagai jalan dakwah dan warisan tugas nabi untuk diterapkan dalam praktik jurnalistik. Penelitian ini menganalisa pemikiran Parni Hadi tentang Jurnalisme Profetik, Jurnalisme Islami, dan mengimplementasikan Jurnalisme Profetik. Metodologi penelitian kepustakaan (library research) ini menggunakan pendekatan analisis konten. Hasil penelitian ini menemukan bahwa, Jurnalisme Profetik yang bisa dipraktikan oleh jurnalis atau media massa berbagai latar belakang agama, selama menyajikan produk jurnalistik yang benar, mendidik dan untuk kebaikan seluruh umat, dengan tetap menerapkan tugas nabi tentang kejujuran, mengajak kebaikan, dapat dipercaya, mendidik dan menyampaikan pesan penuh kearifan.
\end{abstract}

Kata Kunci : pemikiran jurnalisme, Parni Hadi, jurnalisme profetik.

\section{PENDAHULUAN}

Masyarakat membutuhkan berbagai informasi yang disajikan media massa atau perusahaan pers. Perkembangan pers masa kini telah membuat masyarakat semakin mudah untuk mendapatkan informasi. Setiap harinya pers menyajikan berbagai laporan penting mengenai bermacam-macam peristiwa fakta, 
Feri Purnama

menyajikan informasi yang penting kepada masyarakat. Tugas kerja dan keunggulan jurnalistik dan pers tersebut dapat menjadi peluang dakwah untuk mewartakan kabar baik dan membuat masyarakat sebagai pembaca, pendengar maupun pemirsa mendapatkan informasi yang bermanfaat bagi kehidupan masyarakat atau umat.

Dakwah melalui media massa dengan sajian karya jurnalistik secara profesional hanya dapat dilaksanakan oleh orang yang berprofesi sebagai wartawan atau pekerja media dalam melaksanakan tugasnya untuk menginformasikan, mendidik (educate) dan mengajak umat atau khalayak pada kebaikan seperti yang diuraikan dalam Al-Quran dan sunnah. Seperti halnya dijelaskan di Al-Quran tentang ajakan pada kebaikan seperti yang dijelaskan dalam QS. An-Nabl: 125 (Mundofir dan Syaikhu, 2014).

Dakwah dalam praktik jurnalistik dapat diterapkan dengan menggunakan konsep jurnalisme profetik (prophetic journalism) artinya jurnalisme kenabian, segala praktiknya berlandaskan cinta, damai dan untuk kebaikan seluruh umat manusia, Rabmatan Lil Alamin. Jurnalisme profetik berdasarkan pandangan penulis dapat diistilahkan hal yang baru dalam khazanah ilmu jurnalistik bidang ilmu komunikasi. Profetik diartikan sebagai nabi atau kenabian menirukan perilaku atau apa yang dicontohkan para nabi yang penuh dengan nilai dan etika. Jurnalisme Profetik dapat dijadikan kajian praktik ilmu jurnalistik yang dapat terintegrasi dengan ilmu komunikasi yang sudah lebih jauh berkembang.

Seiring berkembangnya zaman, metode dakwah tidak harus secara lisan yang dilakukan di mimbar, tetapi dapat dilakukan melalui media tulisan (produk jurnalistik), seperti halnya dikatakan kolumnis juga akademisi Pasca Sarjana Universtias Islam Negeri Sunan Gunung Djati Bandung, Dr. H. Agus Ahmad Safei bahwa cara dakwah harus terus diperbaharui tanpa henti. Dakwah harus berinovasi agar dakwah lebih relevan, lebih mengena, dan lebih bisa mengeksplorasi potensi dan kekuatan umat. Agus Ahmad Safei menyebutkan dalam bukunya Sosiologi Dakwah yakni bagaimana dakwah dikembangkan melalui media tulisan, tidak melulu melakukan pendekatan lisan. Bagaimana tradisi ulama salaf berabad lalu yang banyak menuliskan visi dan pesan dakwahnya ke dalam bentuk buku dibandingkan kembali sebagai sebuah kesadaran umat (Syafei, 2016).

Untuk itu, bagaimana jurnalisme yang berkaitan dengan tulis menulis dapat mengungkapkan gagasan yang bersifat informasi, tujuannya untuk menyerukan kebaikan, sehingga praktiknya saat ini maupun yang akan dating. Menurut aktivis pers mahasiswa IAIN Walisongo, Semarang, Jawa Tengah, juga menjabat sebagai Ketua Sekolah Tinggi Agama Islam Natuna, Umar Natuna dibutuhkan penerapan jurnalisme profetik yang pemberitaannya menyuarakan hak-hak masyarakat agar mendapatkan perhatian dari para pihak-pihak penguasa atau pemangku kebijakan. Melalui tulisannya yang diterbitkan di media online 
Pemikiran Parni Hadi Tentang Jurnalisme

Kompas.com memandang tentang praktik jurnalistik yang seharusnya menyuarakan permasalahan besar di kalangan orang kecil di antaranya tentang ketidakadilan, kejujuran, ketidakberdayaan, dan keterbelakangan, itu semua merupakan materi yang seharusnya mendapat tempat dalam pemberitaan media massa nasional ke depan. Umar Natuna menambahkan bahwa jurnalisme profetik bukan hanya praktik kegiatan menulis atau melaporkan (report) setiap kejadian atau segala peristiwa disajikan dengan lengkap, lebih dari itu yakni jujur, akurat, dan bertanggung jawab. Praktik jurnalisme profetik menyajikan petunjuk ke arah perubahan yang berlandaskan cita-cita dan profetik moral idealisme dengan basis etik. Artinya, jurnalisme bertanggungjawab dan sadar dalam menyajikan nilai semua cita-cita etik serta sosial yang didasarkan terhadap liberasi, emansipasi, dan transendensi. Adanya Jurnalisme Profetik ini menjadi harapan peradaban setiap umat agar lebih tercerahkan. Itulah jurnalistik sesungguhnya untuk dapat dikembangkan dalam pemberitaan di media massa saat ini maupun ke depannya, yang tentunya mampu menempatkan kekuatan etik dan moral sebagai dasar untuk menentukan produk tulisan atau analisis informasi tersebut perlu dipublikasikan kepada khalayak atau tidak, bukan lagi karena komersial atau membela pihak tertentu seperti pemilik modal (Kompas.com, 2017).

Namun saat ini, pemikiran jurnalisme profetik belum cukup populer, jika ditelusuri dengan menggunakan situs pencari www.google.com atau ensiklopedia maka istilah penyebutan jurnalisme profetik belum terlalu ramai dibahas oleh banyak praktisi maupun akademisi bidang ilmu jurnalistik, berbeda dengan penyebutan nama profetik pada kajian keilmuan lainnya seperti ilmu komunikasi yang telah ditulis Iswandi Syaputra dengan judul buku "Komunikasi Profetik", dan buku "Paradigma Komunikasi Profetik". Selanjutnya buku profetik lain diluar ilmu komunikasi yaitu buku karya Syamsudin SH "Ilmu Hukum Profetik", lalu karya Khoiron Rosyidi yang mengaitkan profetik dalam dunia pendidikan dengan judul bukunya "Pendidikan Profetik" dan karya Prof. Dr. Musa Asy'Arie dengan judul buku "Rekonstruksi Metodologi Berpikir Profetik Perspektif Sunnah Nabi”.

Sebelum munculnya beragam karya tulis paradigma profetik tersebut ternyata telah cukup lama pemikiran profetik dikembangkan oleh Prof. Dr. Kuntowijoyo yaitu pembahasan tentang Ilmu Sosial Profetik yang menjadi salah satu gagasan pentingnya. Selanjutnya muncul pembahasan tentang "Paradigma Profetik Islam" yang ditulis Heddy Shri Ahimsa-Putra hasil telaah secara kritis pemikiran Kuntowijoyo tersebut. Sedangkan pembahasan jurnalisme yang berkaitan dengan pemikiran profetik belum begitu banyak, sepengetahuan penulis pembahasan jurnalistik lebih cenderung mengenai jurnalisme islami dan jurnalisme damai, selebihnya hanya jurnalisme umum. Buku yang spesifik membahas tentang jurnalisme profetik hasil penelusuran di www.google.com maupun sejumlah toko buku di Bandung, Jawa Barat maupun took buku online, 
Feri Purnama

hanya satu yang muncul yaitu buku berjudul "Jurnalisme Profetik" karangan wartawan generasi tua di Indonesia Parni Hadi. Adapun beberapa buku tentang ilmu jurnalistik yang membahas materi jurnalisme profetik hanya tercantum sebagai sub judul dalam buku jurnalistik dengan penjelasan cukup singkat yakni hanya menjelaskan sebagai jurnalisme kenabian.

Jurnalisme profetik sebagai salah satu kajian dari Parni Hadi, sebenarnya sudah ada yang membahas sebelumnya diantaranya adalah tentang, Dialog Antaragama melalui Media: Perspektif dan Keterbatasan Perdamaian Jurnalisme (Hanitzsch, 2003), Peran Jurnalisme Islam di Tengah Hegemoni Pers Barat dalam Globalisasi Informasi (Syah, 2014) dan Jurnalisme Sastra, Dakwah Islam: Analisis Rubrik Nganal-Kodewa Radar Malang (Syaifuddin, 2014) dan Independensi Wartawan PWI Jawa Barat dalam Berita Keislaman (Novita, 2018).

Beberapa penelitian terkait telah dilakukan diantaranya adalah Peran Jurnalisme Islam di Tengah Hegemoni Pers Barat dalam Globalisasi Informasi dalam Jurnal Komunikasi Islam (Kriskayuda, 2012), Kemanusiaan dalam Media: Telaah atas Gaya Jurnalisme Majalah Tarbawi dan Tempo dalam Jurnal Komunika (Santoso, 2010), Etika Dan Prinsip Jurnalisme Media Siber Detikcom Mengenai Mekanisme Pemberitaan Tewasnya WNI di Kerusuhan Mesir (Wibawa dkk, 2012), dan Kemungkinan Bahasa Sastra Diadopsi Jurnalisme dalam Mediator (Santana, 2004). Beberapa kajian tersebut lebih menekankan kepada jurnalisme Islam dan kemanusiaan, etika dan prinsip jurnalisme, sedangkan penelitian ini lebih focus pada pemikiran seorang tokoh jurnalisme yaitu Parni Hadi yang mengkaji tentang jurnalisme profetik, artinya bagaimana kegiatan jurnalisme ini selalu searah dengan pesan-pesan kenabian atau mengikuti ajaran sesuai dengan tuntunan nasbi, atau sesuai tuntunan Islam.

Gambar 1.

Parni Hadi meluncurkan Buku Jurnalisme Profetik di Jakarta.

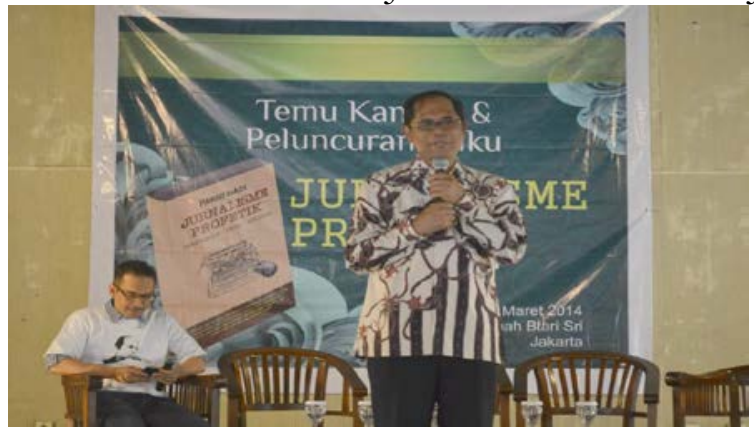

Sumber Foto: https://web.facebook.com/ParniHadi/

Parni Hadi penulis buku "Jurnalisme Profetik" merupakan pekerja media di Indonesia yang dikenal sebagai sosok yang konsisten menggelorakan konsep jurnalisme profetik (Hadi, 2017). Parni Hadi merupakan wartawan senior yang 
Pemikiran Parni Hadi Tentang Jurnalisme

mulai menggeluti karir jurnalistiknya pada 1973 di Lembaga Kantor Berita Nasional (LKBN) Antara yakni satu-satunya kantor berita Pemerintah Indonesia (Tebbel, 2003:36), juga pendiri surat kabar berbasis islami Republika, serta telah cukup banyak menulis, maupun ditulis gagasan pemikirannya tentang menyuarakan jurnalisme profetik. Bukti keseriusan pemikiran profetiknya itu dibuktikan dengan meluncurkan buku berjudul "Jurnalisme Profetik" dengan sub judul "Mengemban Tugas Kenabian" dengan penjelasan isi buku tentang Pergulatan, Pemikiran dan Perenungan Parni Hadi sejak menekuni karir jurnalistik.

Parni Hadi memandang bahwa tugas wartawan menyebarluaskan informasi merupakan suatu kebaikan untuk tujuan kebaikan, dalam agama Islam disebut dakwah bil qalam. Selanjutnya penerapan konsep jurnalisme profetik yang diyakininya adalah mencerdaskan dan mencerahkan. Ide pemikiran jurnalisme profetik yang disuguhkan Parni Hadi merupakan bagian kampanye untuk meneladani sifat Rasulullah seperti jujur (shiddiq), menyampaikan pesan yang mendidik (tabligh), terpercaya (amanab), dan cerdas yang penuh dengan bijaksana (fathanah). Bahkan Parni Hadi dalam konsep jurnalisme profetiknya itu mengajak insan media untuk bisa mengungkap suatu kebenaran, menegakan keadilan, mendukung dalam menciptakan kesejahteraan, bisa mewujudkan atau menciptakan perdamaian, dan mengangkat setinggi-tingginya nilai kemanusiaan secara universal (Hadi, 2015:8).

Sosok Parni Hadi ini lahir di Madiun, Jawa Timur 13 Agustus 1948, dia telah memulai karir jurnalistiknya dari bawah hingga menjajaki pimpinan tertinggi di Lembaga Kantor Berita Nasional Antara. Kemudian Parni Hadi menjadi salah satu perintis menerbitkan Surat Kabar Republika sebuah surat kabar harian yang berbasiskan islami, selanjutnya menjejaki karir jurnalistiknya di lembaga penyiaran milik pemerintah yakni Radio Republik Indonesia (RRI), termasuk aktif berorganisasi pers dalam negeri maupun luar negeri. Usianya yang sudah lewat setengah abad itu masih aktif menulis artikel, termasuk menulis buku dan mengisi materi di berbagai kegiatan akademik maupun seminar tentang kejurnalistikan. Kesibukan aktivitasnya itu Parni Hadi berusaha memaknai profesi wartawan, yaitu tentang profesi wartawan adalah ibadah.

Parni Hadi juga mengasumsikan dalam karya tulisnya di buku "Jurnalisme Profetik" yakni wartawan adalah pewaris tugas nabi dan rasul, seperti yang dijelaskan dalam Al-Quran Surah Saba ayat 28 (Hadi, 2015:8).

Selanjutnya upaya melakukan ajakan kepada orang untuk berbuat kebaikan dan memerangi segala bentuk kejahatan dan menjunjung tinggi kebenaran merupakan tugas yang dilaksanakan oleh wartawan sesuai dengan fungsi pers dan kode etik jurnalistiknya yang sifatnya menyeluruh di muka bumi ini. Parni Hadi memanifestasikan bahwa ajaran nilai yang terkandung dalam agama apa pun yang sangat indah dan dapat diterima semua umat beragama adalah ajaran "cinta", untuk itu Parni Hadi menegaskan dalam bukunya bahwa jurnalisme profetik 
Feri Purnama

dapat disebut sama dengan konsep jurnalisme cinta (Hadi, 2015:5).

Pembahasan jurnalisme profetik menurut pandangan Parni Hadi sebagai proses kegiatan jurnalistik meliputi mencari, mengumpulkan dan mengolah data kemudian menyiarkannya dengan melibatkan olah fisik yaitu olahraga agar tetap sehat secara jasmani, selain itu intelektual dan spiritual merupakan awal melaksanakan tugas jurnalistik dengan tujuan melayani publik secara kasih sayang tanpa memandang siapa saja yang harus diberitakan, dari suku mana, ras mana, budaya mana, agama apa dan ideologinya apa. Meskipun landasan jurnalisme profetik itu bukan berarti harus lemah atau toleran terhadap segala bentuk kriminalitas kemanusiaan, seperti halnya korupsi, tetapi jurnalisme profetik sebaliknya, yaitu berani menyerukan perang kepada segala tindak kejahatan manusia seperti perilaku korupsi (Hadi, 2015:8).

Sedangkan fungsi jurnalisme profetik seperti yang dijelaskan Parni Hadi yaitu bersifat memberikan informasi, mendidik, kemudian memberi informasi yang sifatnya menghibur, lalu mengadvokasi, memotivasi dan berupaya melayani public, sehingga bagaimana sebuah kegiatan jurnalisme dapat merangsang elemen masyarakat untuk berpartisipasi saling membantu (Gama, 2009). Upaya mewujudkan fungsi itu diperlukan banyak persayaratan yakni kebebasan, independensi, keadilan, kebenaran, kesejahteraan dan perdamaian bagi kehidupan hidup masyarakat, termasuk juga bagaiaman menyajikan sebuah berita secara akurat (Juditha, 2013). Parni Hadi dalam bukunya meyakini bahwa jurnalisme profetik sebagai genre baru jurnalisme yang dibutuhkan untuk media massa di Indonesia, dan bahkan dunia saat ini. Bersamaan dengan siapa saja memiliki kebebasan jurnalisme untuk berekspresi yang bisa dilakukan penyebarannya dengan cepat, serta menjangkau khalayak, siapa pun, tidak terbatas karena adanya kemajuan sebuah teknologi informasi. Untuk itu, jurnalisme profetik dapat berperan melakukan kontrol terhadap para penyebar informasi dengan landasan iman, dan agama, apa pun agama yang dianutnya.

Jurnalisme profetik mempersilakan sesuatu melakukan perbuatan yang memberikan manfaat untuk masyarakat luas, contohnnya seperti aksi kepedulian sosial, melakukan dakwah bil qalam yakni lewat informasi dan dakwah bil hal lewat aksi yang memberikan manfaat untuk orang lain, sehingga mampu menciptakan sebuah stigma, bahwa jurnalis juga bisa melakukan banyak hal terkait dengan kesalehan social, sehingga orang tertarik dan tidak ragu untuk mengemban profesi seorang jurnalis (Paranggani dkk, 2014). Parni Hadi juga mengajarkan tentang kepiawaian tugas jurnalistik dan juga mengembangkan kepada kepekaan dan naluri, menuju kecerdasan spiritual. Menurut Parni Hadi tugas wartawan yaitu bekerja dengan ketangkasan fisik, kemudian kecerdasan secara intelektual, sosial, dan kecerdasan spiritual.

Terkait pemaparan di atas, peneliti tertarik untuk meneliti, dan mengetahui pemikiran Parni Hadi sebagai objek tentang gagasan jurnalisme profetik secara 
Pemikiran Parni Hadi Tentang Jurnalisme

ilmiah. Alasan lain meneliti pemikiran Parni Hadi yaitu secara subjektif sebagai pekerja media yang konsisten mengampanyekan jurnalisme profetik untuk menyebarkan kebaikan dan memberikan manfaat bagi kehidupan seluruh umat manusia melalui informasi. Peneliti juga tertarik bahwa Parni Hadi sebagai muslim berusaha menjadikan kegiatan jurnalistik bagian dari ibadah dan berdakwah. Parni Hadi juga dapat dikatakan sebagai tokoh pers berdasarkan peraturan yang diterbitkan Dewan Pers Nomor 1/Peraturan-DP/II/2010 yakni tentang Standar Kompetensi Wartawan yakni tokoh pers atau wartawan nasional yang reputasi dan karya jurnalistiknya telah diakui masyarakat pers dengan usianya 50 tahun ketika Standar Kompetensi Wartawan (UKW) diberlakukan, dapat diterapkan memiliki kompetensi wartawan.

Untuk itu, penelitian berjudul "Pemikiran Parni Hadi Tentang Jurnalisme Profetik" ini relevan dengan keilmuan Komunikasi dan Penyiaran Islam dalam mewujudkan kegiatan jurnalistik yang bermanfaat bagi umat Islam dan seluruh umat di dunia. Selain itu, penulis menilai masih minimnya pemikiran mengenai jurnalisme profetik di Indonesia sehingga dipandang perlu untuk menelitinya dengan objek penelitian tokoh pers atau wartawan senior yang dinilai intens mengembangkan paham jurnalisme profetik di Indonesia.

Pemikiran bisa disimpulkan dengan diungkapkan oleh manusia, artinya dalam penelitian ini objek penelitian yaitu Parni Hadi yang selama ini tumbuh berkembang sebagai muslim dan menekuni karirnya di dunia media massa ternama di Indonesia. Berdasarkan latar belakang profesi Parni Hadi itu menjadi suatu kewajaran apabila melahirkan gagasan dan pemikiran tentang menerapkan konsep jurnalisme profetik seperti halnya pemikir-pemikir lain yang mengembangkan ilmu tentang keprofetikan seperti Kuntowijoyo seorang budayawan, sejarahwan yang mengembangkan sosial profetik, kemudian Iswandi Syahputra yang menulis buku tentang Komunikasi Profetik. Maka dapat dideskripsikan bahwa objek telaah sekaligus kerangka berpikir dalam penelitian ini meliputi pemikiran jurnalisme profetik yang dikembangkan Parni Hadi.

Penelitian ini didasarkan pada teori tentang komunikasi massa yakni penyampaian pesan (massage), gagasan (ide), atau informasi (inform) yang ditujukan pada orang banyak melalui macam-macam media. Sedangkan pengertian media massa dan komunikasi massa singkatan dari media yang melakukan komunikasi kepada massa merupakan Channel of communication, yakni alat, saluran atau sarana yang dipergunakan untuk proses komunikasi massa (Romly, 2005:4). Definisi paling sederhana berkaitan degan komunikasi massa seperti yang dirumuskan Bittner (1980:10): "Mass communication is messages communicated through a mass medium to a large number of people" artinya komunikasi massa merupakan pesan yang disampaikan melalui media massa pada banyak orang. Jalaludin Rahmat dalam buku komunikasi, 2005:188 menyebutkan arti komunikasi massa lain menurut Gerbner (1967) "Mass communicationis the technologically and institutionally based production and distribution of the most broadly shared continous flow of messeges in industrial 
Feri Purnama

societies" yaitu komunikasi massa merupakan produksi dan distribusi berdasarkan teknologi dan lembaga dari arus pesan yang berkelanjutan serta paling luas dimiliki masyarakat industri.

Komunikasi massa yang dibahas di sini yakni komunikasi massa secara masa kini (modern) dengan media massa salurannya. Salurannya atau bentuknya seperti dijelaskan para pakar komunikasi tidak ada kesepakatan; ada yang menyebutnya dengan pengertian secara luas, misalnya koran atau surat kabar, majalah, radio, televisi, film, buku, rekaman, video, rekaman audio, poster, dan banyak lagi. Ada juga yang membatasinya hanya pada koran, majalah, radio, televisi, dan film (Effendy, 2004:26).

Komunikasi yang dalam serumpunnya terdapat ilmu jurnalisme yakni kegiatan untuk menyampaikan gagasan dan informasi dalam bentuk tulisan, gambar dan suara serta gabungan gambar dan suara yang meliputi proses pencarian, mengumpulkan, pengolahan dan penyebaran/penyiaran kepada public atau khalayak. Jurnalisme pada dasarnya digerakan oleh orang yang peduli terhadap kepentingan orang banyak. Seseorang tertarik atau terpanggil memasuki dunia jurnalisme atau menjadi jurnalis pada umumnya digerakan karena keinginan untuk bisa berbuat demi kepentingan banyak orang. Sedangkan pemahaman tentang jurnalisme profetik atau jurnalisme kenabian adalah jurnalisme dengan tugasnya mengemban tugas kenabian yaitu menyampaikan pesan-pesan untuk berbuat kebaikan dan menghindari kejahatan berdasar nilainilai luhur ajaran agama dan kearifan universal yang sumber utamanya adalah cinta (Republika online, 2018).

Pemahaman jurnalisme kenabian Parni Hadi yaitu tidak terbatas pada ajaran agama tertentu, tapi pada seluruh ajaran agama, orang suci dan orang arif bijaksana yang bertujuan membawa umat manusia kepada kemuliaan hidup dan menghindari kehinaan dengan cara mengungkapakan kebenaran, keadilan, kesejahteraan, perdamaian, dan kemanusiaan universal. Dalam jurnalisme profetik juga harus ditunjang dengan para pekerja atau wartawannya yang profetik yaitu orang yang sadar akan panggilan hati nurani dan mau melakukan sesuatu berdasarkan keyakinan dalam beraktualisasi diri dan menjadi bagian ibadah atau berbuat kebaikan, bukan hanya sekadar bekerja mendapatkan gaji dan pujian atau popularitas. Lebih dalam wartawan yang menerapkan konsep profetik memiliki keberanian mengambil risiko untuk keyakinan terhadap kebenaran dan keadilan (Hadi, 2015:8). Semua hal tersebut pada akhirnya melahirkan pola tugas wartawan profetik tertentu. Berikut skema tentang Jurnalisme Profetik dibawah ini.

Skema Gambar Hubungan Horisontal dan Vertikal

ALLA

R AHMAT

42

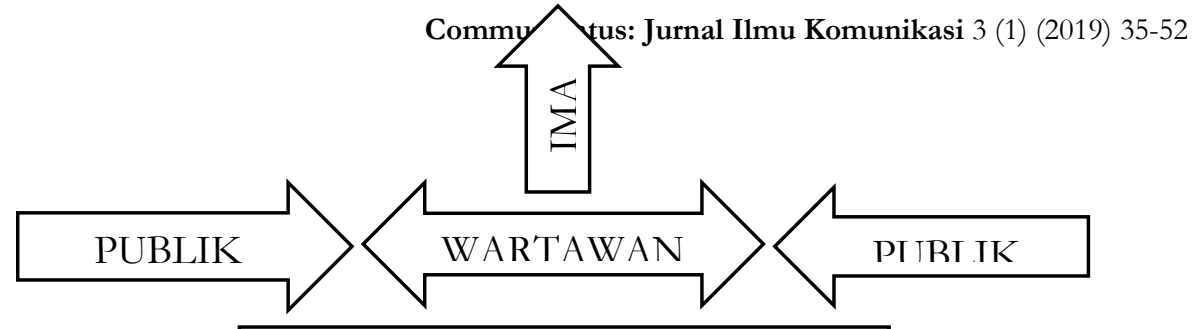


Sumber : Dikembangkan penulis dari buku Parni Hadi, Jurnalisme Profetik.

\section{HASIL DAN PEMBAHASAN}

Objek penelitian ini difokuskan pada tokoh pers senior di Indonesia yakni Parni Hadi yang sudah puluhan tahun terjun di dunia wartawan mulai era Orde Baru atau saat kepemimpinan pemerintahan Indonesia oleh Soeharto hingga saat ini era Presiden Joko Widodo masih menggeluti dunia pers. Sosok Parni Hadi ini memiliki pemikiran tentang Jurnalisme Profetik yang dituangkannya melalui karya buku, artikel, essai dan pernyataannya setiap mengisi seminar tentang kejurnalistikan, bahkan pemikirannya pun pernah ditulis di sejumlah media massa cetak maupun online bahkan sesekali dipublikasikan di layar televisi nasional.

Parni Hadi lahir di Madiun, Jawa Timur 13 Agustus 1948 itu telah memulai karir jurnalistiknya dari nol yakni mulai bekerja sebagai wartawan di Lembaga Kantor Berita Nasional (LKBN) Antara yakni satu-satunya kantor berita Pemerintah Indonesia tahun 1973, hingga menjajaki pimpinan tertinggi di Lembaga Kantor Berita Nasional Antara. Dia juga salah satu perintis Surat Kabar Republika sebuah surat kabar harian yang berbasiskan islami, selanjutnya menjejaki karir jurnalistiknya di Radio Republik Indonesia (RRI), termasuk terlibat dalam sejumlah organisasi pers dalam negeri maupun luar negeri.

Parni Hadi juga telah mampu membuktikan keseriusan pemikiran jurnalisme profetiknya dengan meluncurkan buku berjudul "Jurnalisme Profetik" dengan sub judul "Mengemban Tugas Kenabian" isi buku itu menjelaskan tentang pergulatan, pemikiran dan perenungan Parni Hadi sejak terjun ke dunia karir jurnalistik.

Dia memandang bahwa tugas wartawan menyebarluaskan informasi merupakan suatu kebaikan untuk tujuan kebaikan, dalam agama Islam disebut dakwah bil qalam. Selanjutnya penerapan konsep jurnalisme profetik yang diyakininya adalah mencerdaskan dan mencerahkan. Ide pemikiran jurnalisme 
Feri Purnama

profetik yang disuguhkan Parni Hadi merupakan bagian kampanye untuk meneladani sifat Rasulullah seperti shiddiq (jujur), tabligh (menyampaikan dengan cara mendidik), amanah (terpercaya), dan fathanah (cerdas penuh kebijaksanaan).

Bahkan Parni Hadi dalam konsep jurnalisme profetiknya itu mengajak insan media untuk mengungkap kebenaran (trutb), menegakan keadilan (justice), mendukung terciptakan kesejahteraan (prosperty), mampu menciptakan perdamaian (peace), dan menjunjung tinggi nilai kemanusiaan universal (universal bumanity).

\section{Awal Gagasan Pemikiran Jurnalisme Profetik}

Pemikiran Jurnalisme Profetik yang digagas Parni Hadi berawal sebagai ideografi. Gagasannya itu merupakan hasil pergulatan dan ketekunannya menjalani profesi jurnalistik sejak era Orde Baru atau pemerintahan Presiden Soeharto hingga era Reformasi yang akhirnya mulai menuangkan gagasannya tentang Jurnalisme Profetik menjadi karya buku berjudul "Jurnalisme Profetik" yang diterbitkan Dompet Dhuafa pada Maret 2014.

Jurnalisme menurut Parni Hadi adalah kegiatan untuk menyampaikan pesan (gagasan/ide dan informasi) dalam bentuk tulisan, gambar dan suara yang meliputi proses pencarian, pengumpulan, pengolahan dan penyebaran/penyiarannya kepada orang banyak atau publik. Jurnalisme digerakan oleh orang orang yang peduli akan kepentingan orang banyak (publik). Seseorang tertarik atau terpanggil memasuki dunia jurnalisme atau menjadi jurnalis (praktisi media) pada umumnya karena digerakan oleh keinginan untuk peduli dan berbuat demi kepentingan orang banyak (Hadi, 2017:135).

Terkait penyebutan nama istilah Jurnalisme Profetik (Prophetic Journalism) oleh Parni Hadi berawal saat memimpin Surat Kabar Republika tahun 1996 dalam sebuah tulisan memaknai koran Republika di usia tiga tahun. Saat itu, Parni Hadi mulai menyebutkan istilah Jurnalisme Profetik yakni jurnalisme nabi atau dalam bahasa Inggris nabi artinya prophet, jurnalisme yang mencerdaskan dan mencerahkan.

Parni Hadi menegaskan bahwa tugas wartawan atau dalam setiap kegiatan kejurnalistikannya harus meneladani akhlak mulia Nabi Muhammad saw sebagai pemberi kabar baik yang benar. Praktiknya adalah sebagai jurnalisme cinta, untuk itu dalam gagasannya Parni Hadi disampaikan dalam berbagai kegiatan di dalam negeri, maupun acara di tingkat internasional. Dengan demikian istilah Jurnalisme Profetik dapat dikenal dan bisa diimplementasikan di seluruh dunia dengan tujuan melaksanakan tugas jurnalistik secara baik-baik, penuh dengan cinta seperti yang diharapkan Parni Hadi.

Sebelum muncul gagasannya tentang Jurnalisme Profetik, Parni Hadi bergulat memikirkan tentang makna profesi wartawan yang tugas utamanya hanya memproduksi, dan melaporkan berita dari hasil liputan peristiwa fakta. Ia menyimpulkan profesi wartawan tidak hanya menyampaikan informasi tetapi 
Pemikiran Parni Hadi Tentang Jurnalisme

lebih dari itu ada kekuatan informasi, informasi sebagai kekuatan dahsyat yang dapat mengubah banyak hal. Parni Hadi meminjam pernyataan Napoleon Bonaparte seorang pemimpin militer dan politik Perancis yang menjadi terkenal saat Perang Revolusioner bahwa pena wartawan lebih tajam dari pedang. Pernyataan yang membanggakan itu, ditanggapi Parni Hadi bahwa menjadi wartawan berarti mengemban tugas mulia dan sekaligus tanggungjawab besar bagi kemaslahatan public dan kemanusiaan. Jika profesi wartawan dilakukan dengan cara tidak benar atau asal-asalan, tidak akurat dan tidak didorong demi kepentingan umum, maka menurut Parni Hadi akan menjadi dosa besar profesi (Hadi, 2017: 4).

Paham Jurnalisme Profetik ini terus dikampanyekan Parni Hadi dengan mengimbau siapa saja yang bergerak di bidang penyebaran informasi, tidak hanya wartawan yang bekerjad di media professional, tetapi masyarakat umum yang menjalankan tugas wartawan (citizen journalists) dan penyedia berita dan gambar warga (content providers) melalui media massa dan media social untuk kembali kepada kewajiban menaati ajaran agama masing-masing dan Kode Etik Jurnalistik agar terhindar dari dosa profesi.

Parni menjelaskan tentang Jurnalisme Profetik atau jurnalisme kenabian yang berbeda dengan genre-genre jurnalisme lainnya. Yakni mengajak orang dalam menyebarkan informasinya sebagai gerakan berbuat baik, dan melawan setiap kejahatan untuk kebaikan bersama seluruh umat manusia. Tujuan utama dari Jurnalisme Kenabian itu, kata Parni, untuk mendapatkan rahmat dari Allah, bukan hanya untuk popularitas, uang dan kedudukan.

Pernyataan Parni Hadi tersebut menunjukan bahwa profesi wartawan tidak hanya sekedar mencari kebutuhan hidup, tetapi jauh lebih dari itu untuk melayani masyarakat dan mewujudkan kepentingan umum lebih utama sebagai tugas menjalankan ajaran agama di bidang penyebaran informasi yang bermanfaat.

\section{Pengaruh Lahirnya Jurnalisme Profetik}

Setiap manusia menunjukan gagasan dan pemikirannya tentu ada latar belakang kehidupan atau pengalaman pendidikannnya secara formal maupun nonformal, semua tidak lahir atau muncul begitu saja. Kecuali mukjizat yang diberikan Tuhan kepada seseorang seperti halnya para nabi. Begitu pun lahirnya pemikiran Jurnalisme Profetik Parni Hadi tentu memiliki dasar dari pemikiran-pemikiran sebelumnya tentang dunia jurnalistik, yang pada akhirnya dicurahkan menjadi buku tentang Jurnalisme Profetik yang belum pernah dicurahkan pemikiran tersebut oleh akademisi, maupun para praktisi jurnalistik yang lain.

Parni Hadi menjelaskan tentang wartawan atau praktik kegiatan jurnalistik merupakan pewaris tugas para Rasul seperti yang dijelaskan dalam firman Allah Surah al-Kahfi (18:56).

Parni Hadi menilai dalam ayat tersebut tentang kabar gembira dan 
Feri Purnama

peringatan yang maknanya sama persis seperti tugas wartawan yakni menyampaikan informasi yang mendidik dan menghibur, sekaligus melakukan control social melalui kritik sebagai peringatan. Parni Hadi menyimpulkan tentang ayat tersebut bahwa wartawan adalah pewaris tugas kenabian (Hadi, 2017:6).

Parni Hadi mengungkapkan tentang bukan hanya berita baik dan peringatan yang disampaikan para rasul. Lebih dari itu, yaitu kebenaran. Ini ditegaskan Allah dalam Surah al-Faathir (35:24).

Mengacu pada ayat itu, Parni Hadi menyampaikan tentang kebenaran. Wartawan dilarang menyampaikan kabar bohong atau berita sebagai produk jurnalistik bohong yang tidak berdasarkan fakta di lapangan meliputi kejadian atau pernyataan seseorang sebagai narasumber. Apalagi, ayat yang menegaskan tentang kabar bohong dijelaskan dengan tegas Surah an-Nur (24:11).

Selain mengacu pada ayat suci Al-Quran, praktik jurnalistik juga diatur dalam Kode Etik Jurnalistik yang salah satu pasalnya yakni Pasal 4 bahwa "Wartawan Indonesia tidak membuat berita bohong, fitnah, sadis dan cabul". Parni Hadi menyampaikan KEJ tersebut untuk menghindari berita bohong atau praktik-praktik yang dapat merugikan publik.

Selain itu, Parni Hadi menjelaskan dalam KEJ Pasal 3 mengatakan "Wartawan Indonesia selalu menguji informasi, memberitakan secara berimbang, tidak mencampurkan fakta dan opini yang menghakimi, serta menerapkan azaz praduga tak bersalah". Pasal tersebu menyatakan sama seperti yang dituangkan dalam Surah al-Hujurat (49:6).

Sedangkan praktik check and recheck merupakan keharus wartawan sebagai saksi atas kebenaran. Tentang kesaksian ini Allah berfirman dalam Al-Fath (48:8) yakni "Sungguh, Kami mengutus engkau (Muhammad) sebagai saksi, pembawa berita gembira dan pemberi peringatan" (Al-Majid)

Memperhatikan ayat Al-Quran dan KEJ tersebut, Parni Hadi menemukan pengamalan Jurnalisme Profetik atau Jurnalisme Kenabian sejalan dan dapat diintegrasikan dalam sistem Pers Pancasila di Indonesia. Berikut dijelaskan pernyataannya tentang wartawan sebagai penerus tugas para nabi :

"Saya yakin bahwa wartawan dengan latar belakang agama, bangsa dan ideologi apa pun, mengemban profesi yang sangat mulia. Wartawan meneruskan tugas para nabi dan rasul dari agama apa pun (Hadi, 2017: 7).

Wartawan adalah agen penebar dan pencari berita. Jika berita yang diperoleh dan disampaikan baik, maka masyarakat akan tertular dengan kebaikan tersebut. Tapi kalau yang disampaikannya berita buruk dan bohong, maka keburukan itu akan menjadi virus ditengah masyarakat. Saya tergerak untuk mengingatkan siapa saja yang bergerak di ranah informasi untuk kembali kepada menaati ajaran agama masing-masing dan kode etik jurnalistik. Untuk itu pulalah saya terdorong menulis risalah "Jurnalisme Kenabian" atau "Jurnalisme 
Profetik" (Hadi, 2017: 97-98).

Pernyataan Parni Hadi tersebut sejalan dengan fungsi pers seperti yang dijelaskan dalam buku Ilmu Komunikasi karya Onong Uchjana Effendy di antaranya adalah menyiarkan informasi (to inform), mendidik (educate), dan mempengaruhi (to influence). Menyiarkan informasi merupakan fungsi pers yang pertama dan utama. Khalayak pembaca berlangganan atau membeli surat kabar karena memerlukan informasi mengenai berbagai hal di bumi ini, mengenai peristiwa yang terjadi, gagasan atau pikiran orang lain, apa yang dilakukan oleh orang lain, apa yang dikatakan orang lain, dan sebagainya (Effendy, 2004: 149).

\section{Jurnalisme Profetik dan Jurnalisme Islami}

Parni Hadi mengungkapkan perbedaan antara pemikiran Jurnalisme Profetik dengan Jurnalisme Islam, dan Jurnalisme Islami. Secara sepintas pemahaman Jurnalisme Profetik tentu memiliki kesamaan dengan jurnalisme lainnya yang mengedepankan kebenaran. Segala praktik jurnalistik tentu sesuai dengan kaidahnya adalah menyampaikan informasi atau peristiwa fakta untuk disebarluaskan ke khalayak. Namun dalam pemikiran Parni Hadi tentang Jurnalisme Profetik itu memiliki pemahaman dan sistem kerja jurnalisme yang berbeda.

Parni Hadi memaparkan tentang pemahaman Jurnalisme Islam dan Jurnalisme Islami dalam karya bukunya Jurnalisme Profetik menjelaskan dua jurnalisme itu telah telah memunculkan perdebatan panjang. Masalah itu karena menerapkan label "islam" setelah kata "jurnalisme" sehingga melahirkan ragam pendapat. Parni Hadi menjelaskan ada pendapat yang mengatakan bahwa jurnalisme bersifat universal dan karena itu praktiknya menerapkan kode etik Jurnalistik, dan pada dasarnya jurnalisme sebenarnya telah memuat nilai-nilai keislaman.

Parni Hadi menyatakan tentang pemikiran Jurnalisme Islami yakni praktik jurnalistik yang berdasarkan Alqur'an dan hadits Rasulullah saw. Dalam pandangan tentang Jurnalisme Islam Parni menilainya seperti pada sabda Rasulullah yaitu sebaik-baik manusia adalah yang paling bermanfaat bagi orang lain. Untuk itu menurut Parni sekalipun mengusung panji-panji Islam, kalau tidak banyak manfaatnya, praktik jurnalisme itu belum islami (Hadi, 2017: 113).

Parni Hadi berpendapat bahwa Jurnalisme Islami adalah jurnalisme yang meneladani kode etik Nabi Muhammad saw, yang ternyata sesuai dengan fungsi media, yakni: shiddiq (menyampaikan, to inform), amanah (mendidik, to educate), tabligh (menghibur, to entertain), dan fathanah (melakukan kontrol sosial, social control). Keempatnya juga bisa diartikan : shiddiq (berdasrakan kebenaran), tabligh (disampaikan dengan cara mendidik), amanah (dapat dipercaya), dan fathanah (dengan penuh karifan) (Hadi, 2017: 113).

\section{Implementasi Pemikiran Jurnalisme Profetik Parni Hadi}


Feri Purnama

Parni Hadi mengimplementasikan pemikirannya tentang jurnalisme profetik kepada masyarakat, terutama wartawan, maupun mahasiswa sebagai kaum intelektual. Parni menyebutkan ada dua implementasi jurnalisme profetik yakni sebagai dakwah Bil Qalam dan dakwah Bil Hal

Parni Hadi mengaplikasikan Jurnalisme Profetik sebagai dakwah bil qalam meliputi dua bentuk yakni pertama penyampaian informasi atau dakwah bil qalam, dan kedua yakni aksi yang digerakan oleh informasi atau dakwah bil hal. Informasi adalah sesuatu dalam bentuk tulisan, gambar dan suara yang disampaikan kepada pihak lain untuk mencapai tujuan tertentu yang dikehendaki. Penyampaian informasi atau dakwah bil qalam dengan aktif menulis berbagai pandangan kehidupan sosial, politik maupun bangsa, selain menyampaikan tentang informasi pemikiran Jurnalisme Profetik.

Parni Hadi menyampaikan tentang wartawan yang memproduksi berita tetapi sifatnya mengadu domba maka dari itu tidak dapat dikatakan sebagai jurnalis kenabian. Untuk itu, dalam tulisannya Parni Hadi menegaskan bahwa wartawan bukan provokator yang dapat merugikan publik.

\section{PENUTUP}

Pemikirann tentang Jurnalisme Profetik yang berhasil disajikann Parni Hadi berawal dari pengalamannya menjadi wartawan, termasuk menghadapi berbagai persoalan dampak baik dan negatif dalam melaksanakan tugas jurnalistik maupun hasil dari produk jurnalistik berupa pemberitaan. Pengalaman wartawannya itu telah membentuk cara bepikirnya yang melahirkan penyebutan istilah Jurnalisme Profetik (Prophetic Journalism). Penyebutan istilah itu mulai berani diungkapkan Parni Hadi kepada publik saat memimpin Surat Kabar Republika tahun 1996 dalam sebuah tulisan memaknai koran Republika di usia tiga tahun.

Pemikiran Jurnalisme Profetik Parni Hadi adalah meneladani akhlak mulia Nabi Muhammad saw sebagai pemberi kabar baik yang benar. Yang dapat diimplementasikan di seluruh dunia untuk tujuan melaksanakan tugas jurnalistik dengan damai dan memberikan manfaat. Parni Hadi dalam pemikirannya itu memiliki pesan yang bersifat ajakan kepada orang yang terjun dalam penyebaran informasi media massa professional maupun jurnalisme warga untuk melakukan gerakan berbuat baik, menyebarkan informasi yang menyejukan, mendamaikan dan berani melawan setiap kejahatan untuk kebaikan bersama seluruh umat manusia. Tidak semata mencari keuntungan pribadi secara finansial atau popularitas melainkan untuk mendapatkan rahmat dari Allah swt. Pemikirannya tentang Jurnalisme Profetiknya itu diperkuat dengan landasan berpikir yang dapat dipertanggungjawabkan dengan referensi hadits dan ayat-ayat Al-Quran yang berhubungan dengan segala perbuatan dalam kegiatan jurnalistik atau kewartawanan. 
Pemikiran Parni Hadi Tentang Jurnalisme

Jurnalisme Profetik merupakan praktik dari Jurnalisme Islami, yaitu segala kegiatannya berdasarkan landasan islami, berbeda dengan jurnalisme genre lainnya seperti Jurnalisme Islam yang bersifat ekskluif yang dilakukannya oleh orang-orang Islam dengan misi jurnalistiknya mengedepankan nuansa Islam sesuai hadits dan Al-Quran. Sedanhgkan Jurnalisme profetik ini merupakan jurnalisme yang mengimplementasikan jurnalisme secara islami, yang tentunya bersifat universal, tidak eksklusif, tetapi bisa diterapkan oleh jurnalis nonmuslim yang tujuannya jurnalisme yang menyejukan, mendamaikan dan memberikan manfaat bagi seluruh umat manusia. Ada pun media yang mengusung panji-panji Islam, tetapi jika tidak banyak manfaatnya, maka praktik jurnalisme itu belum islami. Jurnalisme Profetik yaitu meneladani Nabi Muhammad saw yang sesuai dengan fungsi media, yakni: shiddiq (menyampaikan, to inform), amanah (mendidik, to educate), tabligh (menghibur, to entertain), dan fathanah (melakukan kontrol sosial, social control). Keempatnya itu bisa diartikan sebagai shiddiq (berdasrakan kebenaran), tabligh (disampaikan dengan cara mendidik), amanah (dapat dipercaya), dan fathanah (dengan penuh karifan).

Parni Hadi mengaplikasikan Jurnalisme Profetik sebagai dakwah bil qalam dan dakwah bil hal. Dakwah bil qalam meliputi penyampaian informasi meliputi tulisan, gambar, dan suara, dan dakwah bil hal melakukan aksi nyata yang digerakan oleh informasi. Parni Hadi telah mengimplementasikan dua metode dakwah itu dengan membuat tulisan atau menyebarkan informasi yang berkaitan dengan nuansa jurnalisme profetik. Sedangkan Jurnalisme Profetik sebagai dakwah bil hal diterapkan dengan menjalankan aksi sosial nyata dengan terlibat dalam berbagai organisasi kemanusiaan sebagai bentuk pertanggungjawaban Parni Hadi terhadap Jurnalisme Profetik.

Hasil penelitian yang telah dilakukan terdapat beberapa rekomendasi yang dapat menjadi bahan pertimbangan bagi Parni Hadi untuk lebih menyebarluaskan paham pemikiran Jurnalisme Profetik ke seluruh kalangan media, terutama jurnalis, tidak hanya kepada kalangan jurnalis muslim tetapi seluruh jurnalis non muslim agar menjadi pedoman mutlak dalam menjalankan tugas jurnalistik sehingga menghasilkan produk jurnalistik yang tidak hanya isinya berita normatif tetapi berita yang berani dan mencerdaskan.

\section{DAFTAR PUSTAKA}

Effendy, O. U. (2004). Ilmu Komunikasi, Bandung: Rosda.

Gama, B. 2009). Jurnalisme Bencana dan Rangsangan Emosional Studi Hubungan Jurnalisme Bencana Banjir Surat Kabar Solopos dengan Rangsangan Emosional Mahasiswa Univet Bantara Sukoharjo. Scriptura $3(1)$.

Hadi, P. (201)2. Pelatihan Kode Etik Jurnalistik dan Uji Kompetensi Wartawan, Jakarta.

Communicatus: Jurnal Ilmu Komunikasi 3 (1) (2019) 35-52 
Feri Purnama

Hadi, P. (2017). Jurnalisme Profetik, Jakarta : Dompet Dhuafa.

Hanitzsch, T. 2003). Dialog Antaragama melalui Media: Perspektif dan Keterbatasan Perdamaian Jurnalisme. MediaTor: Jurnal Komunikasi, 4(1).

Juditha, C. (2013). Akurasi Berita dalam Jurnalisme Online (Kasus Dugaan

Korupsi Mahkamah Konstitusi di Portal Berita Detiknews). Jurnal Pekommas, 16(3).

Kriskayuda, B. (2012). Jurnalisme Damai dalam Berita Konflik Pemain Timnas Indonesia dan Wim Rijsbergen pada Koran Harian Suara Merdeka. Jurnal Interaksi, 1(1).

Kurnia, S. S. (2002). Jurnalisme Investigasi. Mediator, 3(1).

Latif, L. (2016). Pemikiran Imam Al-Ghazali tentang Pendidikan Akhlak, Pasca Sarjana Pendidikan Agama Islam. Tesis, Universitas Islam Negeri Maulana Malik Ibrahim, Malang.

Lestari, R. D. (2015). Jurnalisme Kloning, Praktik Plagiarisme Karya Jurnalistike di Kalangan Jurnalis (Studi Kasus Praktik Jurnalisme Kloning di Kalangan Jurnalis di $D I Y)$, Tesis, Universitas Gadjah Mada

Lisa, L. (2014). Kecenderungan Konten Berita Jurnalisme Warga dalam Portal Desa Jejaring Gerakan Desa Membangun pada 2011-2013. Jurnal Ilmu Pengetahuan dan Teknologi Komunikasi, 16(2).

Masri, S. (2005). Etika Jurnalistik Dalam Pandangan Islam. Tesis, IAIN Alauddin Ujung Pandang.

Mestika, Z. (2008). Metode Penelitian Kepustakaan, Jakarta: Yayasan Obor Indonesia.

Mundofir, S. dan Ahmad, S. (2014). Al-Majid, Al Quran Terjemah dan Tajwid Warna, Jakarta:Penerbit Beras.

Musa, A. (2016). Rekonstruksi Metodologi Berpikir Profetik, Yogyakarta: Lembaga Studi Filisafat Islam.

Novita, L. (2018). Independensi Wartawan PWI Jawa Barat dalam Berita Keislaman. Communicatus: Jurnal Ilmu Komunikasi, 2(1), 71-90.

Paranggani dkk. (2014). Pengaruh Intensitas Mengkonsumsi Program Televisi Bermuatan Jurnalisme Warga dan Partisipasi Coaching Citizen Journalism terhadap Minat Mahasiswa menjadi Jurnalis Warga. Interaksi Online, 2(5).

Redana, B. (2009). Jurnalisme dan Filsafat. Melintas, 25(2).

Santana, S. (2004). Kemungkinan Bahasa Sastra Diadopsi Jurnalisme. Jurnal Mediator, 5(1).

Santi. (2007). Jurnalisme Berperspektif Gender. Jurnal Komunikologi, 4(2).

Santoso, E. (2010). Kemanusiaan dalam Media: Telaah atas Gaya Jurnalisme Majalah Tarbawi dan Tempo. Jurnal Komunika, 4(1).

Suhaimi. (2011). Jurnalisme Sastra: Laporan Peristiwa Secara Naratif dan Variatif. Jurnal Komunika, 5(2). 
Syah, H. (2014). Peran Jurnalisme Islam di Tengah Hegemoni Pers Barat dalam Globalisasi Informasi. Jurnal Komunikasi Islam, 4(1).

Syaifuddin, H. (2014). Jurnalisme Sastra dan Dakwah Islam: Analisis Rubrik Nganal-Kodewa Radar Malang. Jurnal Komunikasi Islam, 4(2).

Tri J. Efi., \& Darni. (2014). Kadurjanan Ing Jagading Jurnalisme Sajrone Novel Sang Pangeran Pati Anggitane Fitri Gunawan(Tintingan Sosiologi Sastra). Baradha, 2(3).

Wibawa, A.A dkk. (2012). Etika Dan Prinsip Jurnalisme Media Siber Detikcom Mengenai Mekanisme Pemberitaan Tewasnya WNI di Kerusuhan Mesir. Student e-Journal, 1(1).

Yusuf, S. A. (2012). Konstruksi Konflik dalam Laporan Jurnalisme Sastrawi: Analisis Framing tentang Konstruksi Konflik Aceh dalam Laporan Jurnalisme Sastrawi "Sebuah Kegilaan di Simpang Kraft". Jurnal Ilmu Komunikasi Flow, 1(2). 
Feri Purnama 